\title{
The Influence of Classroom Climate, Learning Interest, Learning Discipline and Learning Motivation to Learning Outcomes on Productive Subjects
}

\author{
Jamilah \\ Gatot Isnani \\ Program Studi Pendidikan Administrasi Perkantoran Universitas Negeri Malang \\ Email : jamilahpadp@yahoo.com; gatotisnani feum@yahoo.com
}

\begin{abstract}
This study aims to determine: (1) class climate, learning interest, learning discipline, learning motivation, and learning outcomes; (2) the effect of class climate on learning outcomes; (3) the effect of learning interest on learning outcomes; (4) the effect of learning discipline on learning outcomes; (5) the effect of learning motivation on learning outcomes; and (6) the dominant effect between class climate, learning interest, learning discipline, and learning motivation on learning outcomes. The population in this study is a tenth grade student that consist of 175 students, a sample of 120 students with used proportionate random sampling technique. The method used is descriptive analysis and multiple linear regression analysis. The results showed that: (1) class climate can be classified good, learning interest can be classified good, learning discipline can be classified good, learning motivation can be classified good, and learning outcomes can be classified quite high; (2) there is no positive effect and significant between class climate on learning outcomes; (3) there is no positive effect and significant of learning interest on learning outcomes; (4) there is no positive effect and significant of learning discipline on learning outcomes; (5) there is no positive effect and significant of learning motivation on learning outcomes; and (6) learning motivation is the dominant variable affecting learning outcomes.
\end{abstract}

Keywords: outcome class climate, learning interest, learning discipline, learning motivation, learning

Education is important thing to be developed in order to meet the future demands and goals to be achieved, this development purpose is to improve the quality in education. Education has an important role for preparing human resources for the development. Education can be considered qualified if measured from position through the role to participate in the intellectual life of the nation and promote the national culture, it is succeed if education can form a generation become smarter, has good character, moral, and personality.

Education field can not be separated from teaching and learning activities. The learning process emphasizes the occurrence of interaction between students, teachers, learning methods, curriculum, facilities, and environmental aspects related to achieving the competence of learning. The success of the learning process is influenced by many factors, both from within students and from outside, such as classroom climate, interest, discipline, motivation, and so forth. Classroom 
climate can be interpreted as the personality of learners who are in the classroom, where classroom conditions will be affected by the personality of students who are in it (Alm \& Laftman, 2016; Pedro, Gilreath \& Berkowitz, 2016; Haukoos \& Penick, 1985). For the final, learning outcomes are the end result of the goal or achievement of a learning process.

Bloom in Hadiyanto (2004: 153) states that "Climate can be interpreted as external conditions, influences, and stimuli which include the physical, social and intellectual influences that affect learners". The conditions of the classroom climate dimensions at each school or even each class is variative and may affect student learning outcomes in the end (Ekpo, Akpan, Essien \& ImoObot, 2009; Yu, 2015; Thamilselvi \& Sekar, 2014). Where the implication is the lower of class climate is built, the lower of learning outcomes obtained by students. Similarly, the higher of classroom climate is built, the higher of learning outcomes obtained by students.

In addition to classroom climate as an external factor, there are internal factors that affect learning outcomes are interest in learning. Slameto (2010: 57) explains "Interest is a constant tendency to pay attention and remember some activities". Interest is a very important thing in learning to smooth the learning process. The growing interest in a person will give attention to doing something diligently for long periods of time, more concentrated, easy to remember, and not easily bored with what is learned (Lee, Chao \& Chen, 2011;Ainley, Hidi \& Berndorff, 2002; Li \& Yang, 2016; Harp \& Mayer, 1997).

Another internal factor that also affects the learning outcomes is the discipline of learning. Discipline learning is the adherence of all students to carry out the obligation to learn consciously, so that the changes obtained on him, whether it be knowledge, deeds or good attitude that study at home and study in school (Sumantri, 2010: 122). Discipline learning aims to increase the sense of responsibility in self and make learners more diligent in the learning process (Somayeh, SayyedMirshah, SayyedMostafa \& Azizollah, 2013; Simba, Agak \& Kabuka, 2016; Laird, Shoup, Kuh \& Schwarz, 2008; 'Brien \& Morris, 2011).

In addition to learning interest and learning discipline, other internal factors that also affect the learning process is the learning motivation. Mc Donald in Hamalik (2003: 158) states that "Motivasi adalah perubahan energi dalam diri seseorang yang ditandai dengan timbulnya perasaan dan reaksi untuk mencapai tujuan". Understanding the motivation put forward by Mc. Donald contains three important elements, namely; (1) Motivation starts from the energy change in the person, (2) Motivation is characterized by feelings of affective arousal, (3) Motivation marked by reactions to achieve the goal (Vibulphol, 2016; Lee, 2010). Learning motivation can arise because of intrinsic factors and extrinsic factors, where in the learning process teaching intrinsic motivation and extrinsic motivation is needed as a driver of self to advance and improve the failure (Feng, Fan \& Yang, 2013; Awad, Al-Haqan \& Moreau, 2017; DePasque \& Tricomi, 2015; Sengodan \& Iksan, 2012). Based on the background that has been described, the hypothesis of this study are:

$\mathrm{H}$ 01: No positivity effect and significant influence from classroom climate variables towards learning outcomes in productive subjects.

$\mathrm{H}$ 02: No positivity effect and significant influence from the variables of learning interest towards learning outcomes in productive subjects. 
$\mathrm{H}$ 03: No positivity effect and significant influence from the variables of learning discipline towards learning outcomes in productive subjects.

$\mathrm{H}$ 04: No positivity effect and significant influence from the variables of learning motivation towards learning outcomes in productive subjects.

\section{METHOD}

In this study, researcher using a quantitative approach, with descriptive correlational for type of research, it refer to the aims of this study is to obtain a description of the variables studied and determine whether there is influence between each variable. The independent variable in this study using four variables, there are classroom climate ( $X_{1}$ ), learning interest $\left(X_{2}\right)$ ), learning discipline ( $\left.X_{3}\right)$ ) and the last one is learning motivation ( $\mathrm{X}_{4}$ ), meanwhile for the dependent variable is the learning outcomes (Y). Population in this research are student of class X SMK Muhammadiyah 5 Kepanjen Malang. Based on the data is obtained from administration department, the total number of students of class X is 175 students. So, for the sample size is based on the Isaac and Michael in Sugiyono (2014: 87) formula. Based on a population of 175 students, if researcher using a table determining, can found the number of samples from a population with a $5 \%$ error rate, finally the sample used in this research was 120 students. This sampling using proportionate random sampling technique that is done by lottery or random. The lottery number according to the student attendance number of each class is then drawn as many as the number of samples per class.

The instruments using a questionnaire, consisting of a number of statements. The questionnaire in this study using a 5 Likert scale with a reply option strongly agree, agree, quite agree, disagree, and strongly disagree. Qualitative data in this research is data in the form of sentences, while the quantitative data obtained from the data processing questionnaires are converted in the form of numbers. In this study, quantitative data are ordinal data were treated as interval data for questionnaires used Likert scale. Primary data in this research is obtained from the statement in accordance with the research variables are classroom climate, learning interest, learning discipline, and learning motivation, meanwhile the secondary data derived from the value of report cards related to cognitive, affective, and psikomotorik on productive subjects of class X students in odd semester 2016/2017 academic year. For the data collection techniques is used questionnaires, and documentation.

This study uses descriptive statistics to describe the classroom climate, learning interest, learning discipline, learning motivation, and learning outcomes of productive subjects. Then using multiple linear regression to determine the effect of partially between classroom climate $\left(X_{1}\right)$, learning interest $\left(X_{2}\right)$, learning discipline $\left(X_{3}\right)$, and the learning motivation $\left(X_{4}\right)$ as independent variables with the learning outcomes (Y) as a dependent variable.

In the regression analysis there are several assumptions that must be met so that the resulting regression equation will be valid if used to draw the conclusions. In this study the researchers used the normality test, multicollinearity test, and heteroscedasticity test. While the autocorrelation test was not used because the data in this study is not included of time series or cross section data. 
Test of this hypothesis is using t tests were used to determine whether there is influence between the independent variables (classroom climate $\left(X_{1}\right)$, learning interest ( $X_{2}$ ), learning discipline ( $X_{3}$ ), and learning motivation ( $\left.X_{4}\right)$ ) and the dependent variable $\mathrm{i}$ (the Learning outcomes (Y)). That the data obtained is accurate, this study using SPSS for windows version 19.

\section{RESULT \& DISCUSSION}

\section{Results}

The description results of this study's show that most of the respondents come from women, the majority are firstborn child in the family, the majority of the last education that Father and Mother rescued is SD Sederajat, the majority of Father's job is private employee and Mother's job is housewife.

After doing research with the 120 students respondents. Class climate has an average score of 4.03 so it can be concluded that the class climate is good. Learning interest has an average score of 3.86 so it can be concluded that learning interest is good. The discipline of learning has an average score of 4.06 so it can be concluded that the discipline of learning is good. Motivation to learn has an average score of 4.11 so it can be concluded that the motivation to learn is good also. Then for the learning outcomes, most of the students have met the Kriteria Ketuntasan Minimal (KKM) so that it can be concluded that student learning outcomes are quite high.

Prior to analysis, the data were tested by using classical assumption test consisting of normality test, multicollinearity test, and heteroscedasticity test. The data in this study has a normal distribution result. So it can be concluded that the regression equation deserve to be used.

The regression equation can be interpreted that class climate can explain the learning outco mes as much as 0.018 or $1.80 \%$, with assumption that other variables are fixed, for the learning interest can explain the learning outcomes as much as 0.022 or $-2.20 \%$ with assumption that other variable is fixed, then the learning discipline can explain the learning outcomes by -0.022 or $-2.20 \%$, with assumption other variables fixed, learning motivation can explain the learning outcomes by 0.043 or $4.30 \%$, with assumption other variables remain. While the constanta of 77.202 for classroom climate ( $X_{1}$ ), learning interest $\left(X_{2}\right)$, learning discipline $\left(\mathrm{X}_{3}\right)$, and learning motivation ( $\left.\mathrm{X}_{4}\right)$ is 0 , it is mean that the learning outcomes (Y) value is 77.202. Also for the coefficient of determination ( $R$ Square Adjusted) is 0.021 , it is showed that there are influences from classroom climate $\left(\mathrm{X}_{1}\right)$, learning interest $\left(\mathrm{X}_{2}\right)$, learning discipline $\left(\mathrm{X}_{3}\right)$ and learning motivation $\left(\mathrm{X}_{4}\right)$ to the student learning outcomes is $-2.1 \%$. The remaining amount of $-97.9 \%$ can be influenced by other variables such as health factors, disability, intelligence, attention, talent, maturity, readiness, fatigue, how parents educate, relationships within the family, the house, the family's economic circumstances, the notion of people old, different cultural backgrounds, the students' activities in society, mass media, friends get along, shape people's lives. The $R$ Square Adjusted is negative for this result, so the value is considered to be 0 , or it can be said the independent variables to be totally can not explain the variance of the dependent variable. 
Table 1. The Influence of Climate Class, Learning Interest, Learning Discipline, and Partial Learning Motivation to Learning Outcomes

\begin{tabular}{ccccc}
\hline Variable Free & t & t table & Sig & Information \\
\hline Climate Class $\left(\mathrm{X}_{1}\right)$ & 0.444 & 1,980 & 0.658 & $\mathrm{H}_{0}$ accepted \\
\hline Learning Interest $\left(\mathrm{X}_{2}\right)$ & -0.394 & 1,980 & 0.694 & $\mathrm{H}_{0}$ accepted \\
\hline Learning Discipline $\left(\mathrm{X}_{3}\right)$ & -0.327 & 1,980 & 0.745 & $\mathrm{H}_{0}$ accepted \\
\hline $\begin{array}{c}\text { Learning Motivation } \\
\left(\mathrm{X}_{4}\right)\end{array}$ & 0.931 & 1,980 & 0.354 & $\mathrm{H}_{0}$ accepted \\
\hline
\end{tabular}

Based on Table 2 it is known that the classroom climate has a significance value of $0.658>0.05$, so there is no positivity effect and significant influence between the classroom climate on learning outcomes. Learning interest has a significance value of $0.694>0.05$, so there is no positivity effect and significant influence between learning interest on learning outcomes. The learning discipline has a significance value of $0.745>0.05$, so there is no positivity effect and significant influence between the learning discipline on learning outcomes. Then for learning motivation has a significance value of $0.354>0.05$, so there is no positivity effect also and significant influence between learning motivation on learning outcomes.

\section{Discussion}

Based on the result of the description for the class climate variable indicates that most students agree on the statement given. The average score of the 19 items statement answer is 4.03 , so it can be concluded that the classroom climate was good. Establishing good relationships with teachers or classmates is important for students, as long as students have a good relationships with teachers or friends, it is make students feel good. Students feel satisfied with the value gained through their own efforts, feel satisfied if it can channel opinions, feel satisfied if able to express its ability. Students involve themselves in various activities in the classroom, students do not find it difficult in understanding the subjects

Students can answer the questions correctly, and solve problems with their own business, it is so productive. Students are encouraged to compete positively to be more active in learning. Adhering to the rules is an obligation for students, students also do not feel burdened with classroom rules even though students sometimes break the rules. Adaptation with new curriculum turnover is easy for students. In-class equipment support the learning process, in addition students feel safe and comfortable with the classroom conditions.

Description of the learning interest variable shows that most students agree on a given statement. The average score of the 10 items of the statement answer is 3.86, so it can be concluded that the learning interest from student is good. Students pay close attention when the teacher explains the material, the students also have a good concentration of learning, so the lessons can be easily accepted by the students. Students learn the material to be given by the teacher first. Students have a good responsibility in collecting tasks on time. Students are also actively questioning and actively discussing about the material being taught. Student selfawareness is also good where it is seen when students do the exercises without 
being appointed by the teacher. The learning method makes it easier for students to receive the material. Learning media also makes students interested and not bored, so that students feel that the subject matter Productive fun to learn.

The description of the learning discipline variables shows that most students agree on the given statement. The average score of the answer of 9 statement items is 4.06 , so it can be concluded that the discipline of learning is good.Students come to school on time, and wear uniforms according to school requirements. Students always bring the textbook Productive subject in accordance with a predetermined schedule. The explanation given by the teacher is well noted by the students. Students also collect the assignments in a timely manner because students assume that it is an obligation. Productive subjects provided by teachers are done by the students on their own. When at home, students use their time well to learn even if there are no repetitions. In addition, students prefer the time to learn rather than play with friends.

Description of the learning motivation variable indicates that most students agree on the given statement. The average score of the 15 items of the statement the answer is 4.11, so it can be concluded that the motivation to learn is good. Students ask friends about the subject matter that is not understood. In addition, students try to learn again to better understand the material provided by the teacher. If there is a difficult question, the student wants to know the correct answer to the question. If you get a bad grade, students try to learn more diligently for better value. Learning with friends makes students feel happy because they can help each other in understanding the subject matter. If there are friends who score higher and can answer questions given by the teacher, this can encourage students to compete positively. Students want to achieve high achievement in school and want to achieve goals in the future, therefore students try to study diligently. Praise, additional points, and rewards gained for the achievement of good learning results, making students more active in learning. But despite not getting praise, extra points, and rewards, students continue to study earnestly.Interesting learning methods make students learn the spirit. Learning media used by teachers also attract students' attention. Parent family one of them also try to help students when having difficulty in learning. Leisure learning environment in the classroom is important because it can make students' desire to learn to increase.

Description of the learning outcomes variables in this study is the value of report cards consisting of cognitive, affective, and psikomotorik all Productive subjects in the odd semester of the 2016/2017 Lesson Year. The description of the learning result is obtained by the description of 120 respondents who studied, most have values with high enough classification, this is indicated by the value of students who have met the value of KKM (Kriteria Ketuntasan Minimal), which is 75. So it can be concluded that majority of student learning outcomes Is quite high.

The result of data analysis shows that there is no positivity effect and significant influence between classroom climate on learning outcomes in Productive subjects. The results of this study are not in accordance with previous research conducted by Pritami, Purwoko \& Savalas (2014: 73) showed that the classroom climate has a positive and significant relationship with student achievement. The results of this study are also not in line with Hadiyanto's opinion (2004: 158) that although the learning achievement is also influenced by many aspects such as 
learning styles, facilities available, the influence of class climate is still very important. There is a differences between the results of research done with previous research, this may be due to different classroom climate with previous research, and different school circumstances. Results of study not only measured by classroom climate that exists, but is thought to be influenced by other factors such as, health factors, disability, intelligence, attention, talent, maturity, readiness, fatigue, how parents educate, relationships between family members, the house, the family's economic situation, understanding parents, different cultural backgrounds, the students' activities in society, mass media, friends get along, shape people's lives (Slameto, 2010: 54-71).

The result of data analysis shows that there is no positivity effect and significant influence between the interest of learning to the learning result on the Productive subject. The results of this study are not in accordance with previous research conducted by Putri \& Isnani (2015: 124) that there is a significant positive influence between the interest on learning outcomes. The results of this study are also not aligned with the opinion Tu'u (2004: 80) that interest and high attention on the subjects will have a good impact on student achievement. Differences between the results of research conducted with previous research, this can be due to the characteristics of students at each school is different, thus causing student interest in learning to productive subjects differently. Results of study not only measured by the level of student interest, but is thought to be influenced by other factors such as, health factors, disability, intelligence, attention, talent, maturity, readiness, fatigue, how parents educate, relationships between family members, the house, the family's economic situation, understanding parents, different cultural backgrounds, the students' activities in society, mass media, friends get along, shape people's lives (Slameto, 2010: 54-71).

The results of data analysis show that there is no positivity effect and significant influence between the learning discipline on the learning outcomes in the subjects Productive. The results of this study are not in accordance with previous research conducted by Widiatmoko \& Suryani (2014: 501) showed that there is a significant positive influence between the learning discipline on student achievement achieved. The results of this study are also not aligned with the opinion Slameto (2010: 67) that discipline makes students become discipline as well, but it also gives a positive influence on the results of learning. Differences between the results of research conducted with previous research, this can be due to the characteristics of students at each school is different, thus causing discipline students learn to productive subjects are different. Results of study not only measured by the discipline of student learning, but is thought to be influenced by other factors such as, health factors, disability, intelligence, attention, talent, maturity, readiness, fatigue, how parents educate, relationships between family members, the house, the family's economic situation, understanding parents, different cultural backgrounds, the students' activities in society, mass media, friends get along, shape people's lives (Slameto, 2010: 54-71).

The result of data analysis shows that there is no positivity effect and significant influence between the learning motivation on the learning result on the Productive subject. The results of this study are not in accordance with previous research conducted by Hamdu \& Agustina (2011: 85) that there is a significant 
positive influence between learning motivation on learning achievement. The results of this study are also not in line with the opinion of Sardiman (2014: 85-86) that the existence of good motivation in learning will show good results. Differences between the results of research conducted with previous research, this can be caused by the characteristics of students at each school is different, thus causing students' learning motivation to productive subjects are different too. Results of study not only measured by the level of student motivation, but is thought to be influenced by other factors such as, health factors, disability, intelligence, attention, talent, maturity, readiness, fatigue, how parents educate, relations between members of the family, the house, the family's economic situation, understanding parents, different cultural backgrounds, the students' activities in society, mass media, friends get along, shape people's lives (Slameto, 2010: 54-71).

The result of data analysis shows that, learning motivation variable is the dominant variable that influence the learning result that is equal to $12,47 \%$. Motivation in learning is one of the things that need to be raised in the effort of learning in school, with the motivation of students will learn harder, tenacious, diligent and have full concentration in the learning process.Students who do not have motivation at the time of learning, it will provide different responses with students who have high motivation, so that if students want to get good learning outcomes, then the motivation is an important factor to note.

This is in line with the opinion of Sardiman (2014: 84) that to learn is needed motivation. Learning outcomes will be optimal if there is motivation.The more appropriate the motivation is, the more successful the lesson will be, so the motivation will always determine the intensity of the learning effort for the students.

\section{CONCLUSION \& SUGGESTION}

\section{Conclusion}

The results of this study indicate that: (1) class climate can be classified well, ilearning interest can be classified well, the learning discipline can be classified well, learning motivation can be classified well, and learning outcomes can be classified high enough; (2) there is no positivity effect and significant influence between the classroom climate on learning outcomes; (3) there is no positivity effect and significant influence between interest in learning on learning outcomes; (4) there is no positivity effect and significant influence between the learning discipline on learning outcomes; (5) there is no positivity effect and significant influence between learning motivation on learning outcomes; (6) learning motivation is the dominant variable affecting the learning outcomes.

\section{Suggestion}

Based on the results of the study, the researcher suggests: (1) for the principal to better build and maintain the discipline habits of students in the school environment by adding strategies to organize and create activity plans in order to foster student discipline; (2) for teachers to have a close relationship with students to have a good impact on learning, assessing and rewarding disciplined students so 
that it is useful to maintain student discipline, learning models to be more varied and contextual to raise awareness Interest in student learning; (3) for students should increase the passion in reading books related to productive materials in order to increase knowledge in accordance with the field of expertise, repeat materials that have been taught teachers in school, and learn regularly in order to improve learning outcomes; (4) for the next researcher, it is necessary to do further research related to other variables that may influence learning result besides class climate, learning interest, learning discipline, and learning motivation.

\section{REFERENCES}

Ainley, M., Hidi, S. \& Berndorff, D. 2002. Interest, Learning, and the Psychological Processes That Mediate Their Relationship. Journal of Educational Psychology, (Online), 94 (3): 545561, (https://pdfs.semanticscho lar.org), diakses 14 Mei 2017.

Alm, S. \& Laftman, S. B. 2016. Future Orientation Climate In The School Class: Relations to Adolescent Delinquency, Heavy Alcohol Use, and Internalizing Problems. Children and Youth Services Review, (Online), 70: 324-331, (http://www.science direct.com), diakses 16 Mei 2017.

Awad, A., Al-Haqan, A. \& Moreau, P. 2017. Motivations, Career Aspiration, and Learning Experience of Students in The Pharmacy Program at Kuwait University: a Tool to Guide Curriculum Development. Currents in Pharmacy Teaching and Learning, (Online), 9 (2): 332-338, (www.sciencedirect. com), diakses 14 Mei 2017.

DePasque, S. \& Tricomi, E. 2015. Effect of Intrinsic Motivation on Feedback Processing During Learning. Neurolmage, (Online), 119: 175-186, (www. sciencedirect. com), diakses 14 Mei 2017.

Ekpo, K., Akpan, O. E., Essien, E. E. \& Imo-Obot, M. M. 2009. Classroom Climate and Students' Academic Achievement in Social Studies in Cross River, Nigeria (Pp. 413-428). An International Multi-Disciplinary Journal, (Online), 3 (4): 413-428, (www.afrrevjo.com), diakses 13 Mei 2017.

Feng, H. Y., Fan, J. J. \& Yung, H. Z. 2013. The Relationship of Learning Motivation and Achievement In Efl: Gender as An Intermediated Variable. Educational Research International, (Online), 2 (2): 5058, (http://www.erint.savap.org. pk), diakses 15 Mei 2017.

Hadiyanto. 2004. Mencari Sosok Desentralisasi Manajemen Pendidikan di Indonesia. Jakarta: PT. Rineka Cipta.

Hamalik, O. 2003. Proses Belajar Mengajar. Jakarta: PT. Bumi Aksara. 
Hamdu, G. \& Agustina, L. 2011. Pengaruh Motivasi Belajar Siswa Terhadap Prestasi Belajar IPA di Sekolah Dasar. Jurnal Penelitian Pendidikan, (Online), 12 (1): 8186, (http://jurnal.upi.edu/pe nelitian pendidikan /view/ 1824/pengaruh-motivasi-belajar- siswa- terhadap-pestasi-belajaripadisekolah-dasar--studi- kasusterhadap-siswa--kelas-iv-sdn-taru managarakecamatan-tawang-kota -tasikmalaya-.html), diakses 7 November 2016.

Harp, S. F. \& Mayer, R. E. 1997. The Role of Interest in Learning From Scientific Text and Illustrations: On the Distinction Between Emotional Interest and Cognitive Interest. Journal of Educational Psychology, (Online), 89 (1): 92102, (http://visuallearningrese arch.wiki.educ.msu.edu), diakses 14 Mei 2017.

Haukoos, G. D. \& Penick, J. E. 1985. The Effects of Classroom Climate on College Science Students: A Replication Study. Journal of Research in Science Teaching, (Online), 22 (2): 163-168, (onlinelibrary.wiley.com), diakses 16 Mei 2017.

Laird, T. F. N., Shoup, R., Kuh, G. D. \& Schwarz, M. J. 2008. The Effect of Discipline on Deep Approaches to Student Learning and College Outcomes. Research in Higher Education, (Online), 49 (6): 469494, (link.springer.com), diakses 16 Mei 2017.

Lee, I. C. 2010. The Effect of Learning Motivation, Total Quality Teaching and PeerAssisted Learning on Study Achievement: Empirical Analysis from Vocational Universities or Colleges' students in Taiwan. The Journal of Human Resource and Adult Learning, (Online), 6 (2): 56-73, (www.hraljournal.com), diakses 16 Mei 2017.

Lee, Y. J., Chao, C. H. \& Chen, C. Y. 2011. The Influences of Interest In Learning and Learning Hours on Learning Outcomes of Vocational College Students In Taiwan: Using a Teacher's Instructional Attitude as The Moderator. Global Journal of Engineering Education, (Online), 13 (3): 140-153, (http://www.wiete.com.au), diakses 14 Mei 2017.

Li, X. \& Yang, X. 2016. Effects of Learning Styles and Interest on Concentration and Achievement of Students in Mobile Learning. Journal of Educational Computing Research, (Online), 54 (7): 922-945, (http://jour nals.sagepub.com), diakses 15 Mei 2017.

O'Brien, A. \& Morris, A. 2011. The Effects of Discipline on The Application of Learning Object Metada in UK Higher Education: The Case of The Jorum Repository. Information Research, (Online), 16 (3): 481, (http://www.infor mationr.net), diakses 16 Mei 2017. 
Pedro, K. T. D., Gilreath, T. \& Berkowitz, R. 2016. A Latent Class Analysis Of School Climate Among Middle And High School Students In California Public Schools. Children and Youth Services Review, (Online), 63: 10-15, (http://www.science direct.com), diakses 16 Mei 2017.

Pritami, S. E., Purwoko, A. A. \& Savalas, L. R. T. 2014. Hubungan Iklim Kelas Dan Sikap Siswa Terhadap Pelajaran Kimia Dengan Prestasi Belajar Kimia Siswa Kelas Xi Ipa Sma Negeri Se-Kota Mataram Tahun Pelajaran 2012/2013. Jurnal Pijar MIPA, (Online), 9 (2): 73-77, (http://jurnalf kip.un ram.ac.id), diakses 7 November 2016.

Putri, D.T.N. \& Isnani, G. 2015. Pengaruh Minat dan Motivasi Terhadap Hasil Belajar Pada Mata

Pelajaran Pengantar Administrasi Perkantoran. Jurnal Pendidikan Bisnis dan Manajemen, (Online), 1 (2): 118-124, (http://journal.um.ac.id/index.php /jpbm/article/view/5040), diakses 7 November 2016.

Sardiman, A.M. 2014. Interaksi dan Motivasi Belajar Mengajar. Jakarta: PT. Rajagrafindo Persada.

Sengodan, V. \& Iksan, Z. H. 2012. Students' Learning Styles and Intrinsic Motivating in Learning Mathematics. Asian Social Science, (Online), 8 (16): 17-23, (www.ccsenet.org), diakses 16 Mei 2017.

Simba, N. O., Agak, J. O. \& Kabuka, E. K. 2016. Impact of Discipline on Academic Performance of Pupils in Public Primary Schools in Muhoroni Sub-County, Kenya. Journal of Education and Practice, (Online), 7 (6): 164-173, (www.iiste.org), diakses 16 Mei 2017.

Slameto. 2010. Belajar dan Faktor-faktor Yang Mempengaruhinya. Jakarta: PT. Rineka Cipta.

Somayeh, G., Sayyed Mirshah, J., Sayyed Mostafa, S. \& Azizollah, A. 2013. Investigating the Effect of Positive Discipline on the Learning Process and its Achieving Strategies with Focusing on the Students' Abilities. International Journal of Academic Research in Business and Social Sciences, (Online), 3 (5): 305-314, (www.hrmars.com), diakses 16 Mei 2017.

Sugiyono. 2014. Metode Penelitian Pendidikan: Pendekatan Kuantitatif, Kualitatif, dan R \& D. Bandung: Alfabeta.

Sumantri, B. 2010. Pengaruh Disiplin Belajar Terhadap Prestasi Belajar Siswa Kelas XI SMK PGRI 4 Ngawi Tahun Pelajaran 2009/2010. Media Prestasi, (Online), 4 (3): 117-131, (http://jurnal.stkipngawi.ac.id/index. php/mp/article/view/53), diakses 7 November 2016. 
Thamilselvi, P. \& Sekar, P. 2014. Classroom Climate At The Higher Secondary Stage. Global Journal For Research Analysis, (Online), 3 (6): 56-58, (www.worldwidejournals.com), diakses 15 Mei 2017.

Tu’u, T. 2004. Peran Disiplin pada Perilaku dan Prestasi Siswa. Jakarta: Grasindo.

Vibulphol, J. 2016. Students' Motivation and Learning and Teachers' Motivational Strategies in English Classrooms in Thailand. English Language Teaching, (Online), 9 (4): 64-75, (www.scribd.com), diakses 16 Mei 2017.

Widiatmoko, A. \& Suryani, N. 2014. Pengaruh Motivasi Belajar dan Disiplin Terhadap Prestasi Belajar Pada Mata Diklat Mengelola Peralatan Kantor Kelas X Jurusan Administrasi Perkantoran SMK Teuku Umar Semarang Tahun Pelajaran 2013/2014. Economic Education Analysis Journal, (Online), 3 (3): 496-501, (http://journal.unnes .ac.id/sju/index.php/eeaj/ article/v iew/4428), diakses 7 November 2016.

Yu, Y. 2015. The Effect of Classroom Environments on University Students' Autonomous EFL Learning. Studies in Literature and Language, (Online), 11 (2): 74-81, (http://www.cscanada.net), diakses 16 Mei 2017. 